\section{Disposal of the Malingerer}

So far as the relation of the malingerer to the Army is concerned, it is essential to consider two points. The first of these is that the man's absence of guilt-feeling concerning his malingering leads to punishment or treatment having no deterrent effect on the future repetition of such conduct. The second point-and this is of the utmost importance in wartime-is the repercusșion which the malingerer's conduct and mental attitude may have upon his Army comrades and, through them, upon military efficiency in general. It has already been pointed out that the malingerer is in a state of extreme emotional immaturity. Consequently, he has broken down in adult circumstances which were successfully withstood by his more strongly constituted brothers-in-arms. In these circumstances he reverts to a state of open childishness. $\mathrm{He}$ may grumble and grouse: his work, his adult capacity for work, falls off ; he continually reports sick and is unappreciative of and does not co-operate in the treatment prescribed; he becomes a burden to all with whom he comes in contact in the environment for which he has a phobic anxiety; he develops the craving to return to his home, where the only real security he knows of is to be found and where his childish immaturity is understood and the pity and sympathy he has always expected from other people are forthcoming.

All this is clear and understandable, and in peacetime one could leisurely endeavour to wean such a case to a more adult independent state. When, however, he is a member of the fighting Services, and when the interests of the individual have of necessity to be subordinated to the group, this is out of the question. It is demanded of him that he "become a man" and "put away childish things"-which he is constitutionally incapable of doing. In his behaviour and attitude he is expected to contribute to the promotion and maintenance of good morale, instead of which he mopes about his group a potential and extremely dangerous menace to good morale in the more susceptible (i.e., the more emotionally immature) of his as yet mentally healthy comrades. Infectivity in these circumstances is as real a threat as the potential infectivity of a typhoid carrier in the physical sphere, as Wittkower et al. (1941) point out.

This constant and dangerous menace to good morale is, in effect, the crux of the matter concerning the disposal of the psychopath of this type in wartime. The report of the unit officers in referring the man to the R.M.O. when ordinary methods of producing correction have failed eloquently testifies to this. The paramount importance of the maintenance of excellent morale among soldiers has been appreciated from the earliest times, as also has its obvious remedy-namely, the ruthless weeding out of all influences adversely affecting morale. Such a view was arrived at by considered inquiry in 1922: "The occurrence of the [psychoneurotic] conditions militates against the efficiency of the Army, swells the sick returns, increases the amount of hospital accommodation and transport required, and absorbs the time and attention of the medical personnel" (War Office Report, 1922c).

The continued presence of these people in any unit thus tends to promote a vicious circle-infection by the psychoneurotic and the psychopath of the more mentally immature of previously mentally healthy subjects, with increase of further frank psychiatric cases and a further lowering of morale. And the morale of an army is a barometer by which the fighting efficiency of that army can be read at a glance.

The removal of a weak link in an otherwise strong chain designed purposely to bear an enormous stress therefore requires no apology. Nor is it, as some might. imagine from a hasty assessment of facts, an admission of culpable failure. The psychiatrist, like the surgeon, can radically treat only those growths that are not beyond the reach of his therapeutic knife. In such cases, however, the psychiatrist is potent, from the prophylactic point of view, in removing a dangerous source of infection. Thereby he contributes not inconsiderably to the promotion of that morale and efficiency in the absence of which a fight is never won.

\section{Summary}

The malingerer is a psychopath with, among other features, a complete absence of guilt-feeling concerning his malingering.

Although he consciously assumes and exploits symptoms of physical or mental illness, the variety of symptom adopted (i.e., whether amnesia, gunshot wound, insanity, or paralysis) is, however, apparently determined by an unrecognized masochistic and very infantile dependent attitude.

Malingering is a defence mechanism employed by a constitutionally weak ego against a real but unreasonable and intense anxiety concerning military service.

The disposal of the malingerer in wartime should be preeminently determined by considerations of military morale and efficiency.

I am indebted to Lieut.-Col. R. J. Rosie, R.A.M.C., for encouragement and permission to pursue these investigations, and to Major J. P. McGuinness, R.A.M.C., for his assistance in Case III and the details concerning his Case V. To both, and to Major T. F. Rodger, R.A.M.C., I am beholden for their constructive criticism of the script of this paper.

REFERENCES

Buinewitsch, K. (1941). Methods of Malingerers summarized in Bulletin of War Medicine, 1, 283.

Henderson, D. K. (1939). Psychopathic States, p. 18, London.

Hurst, Sir A. (1940). Medical Diseases of War, p. 16, London.

(1922b) p. 190; (1922c), p. 169 (0)

Wittkower, E., Rodger, T. F., and Wilson, A. T. M. (1941). Lancet, 1, 531.

\title{
FOREIGN BODIES IN THE ALIMENTARY TRACT
}

\section{BY}

\section{G. O. CHAMBERS, F.R.C.S. \\ Visiting Surgeon to H.M. Prisons}

When Nature has provided so many problems in surgery to occupy scientific attention it seems inconsiderate that man should, by accident or otherwise, go one further by self-mutilation in the swallowing of foreign bodies. These cases, however, tend to provide compensations in the element of surprise and the interest they arouse, and create an atmosphere akin to the treasure hunt until such time as the quarry has been unearthed or retrieved. The excitement of all this inclines to be somewhat tempered by the fact that the majority of these perverse individuals are of dubious use to society and, moreover, in some cases develop a morbid appetite for foreign bodies. For some strange reason they seem to stand abdominal section well and develop peritoneal antibodies that serve them to such good purpose that either septic complications are avoided or their relative dangers are overcome.

This paper refers chiefly to intentional swallowing and not to cases of accident occurring usually in children and normal adults, with whom small articles swallowed-inadvertentlyhave a safe passage. The open safety-pin, fish-bone, or needle may cause trouble by impaction or perforation and necessitate removal. The cases under review are those of adults in detention, in whom the swallowing of large, irregular, and ill-assorted articles is the main feature. Only 3 cases are reported as accidental, and concern the loss of two needles and a small denture.

\section{Psychology of the Intentional Swallower}

The psychological aspect of the intentional swallower is interesting, and varies in type with the environment and mode of life. In all there is an underlying psychological framework of egoism, vanity, and self-attention.

From time immemorial this faculty has been utilized as a means of livelihood in exhibitions such as the swallowing of a sword, watch, or live goldfish-duly returned unharmed from their immersion in the stomach. Proof of the last-named performance was given a few years ago at a medical society in London, where an astute radiologist inserted some small lead shot inside each fish - through its mouth-so that their movements in the performer's stomach could be observed with the 
radiological screen. The possessor of a pharyngeal pouch sometimes uses it as a financial asset for the disappearing-watch trick. An $x$-ray demonstration on a performer of this act at the above meeting was declined, as no doubt he wished it to remain a mystery.

Under conditions of restraint the psychological factor becomes intensified and certain prisoners take up an attitude stubborn, defiant, and antisocial to their surroundings. The mental picture is best described by Dr. W. Norwood East in his interesting book, Medical Aspects of Crime (1936), in which he says: "A few of these prisoners are insane, but the majority are not. Most of them are ignorant of the dangers they incur, and are reckless of injury in their attempt to defy authority or exchange imprisonment for the comforts of a civil hospital. . . . Many offenders who swallow foreign bodies are psychopathic personalities. Vanity prompts others to attempt to secure the admiration of their fellows by these means. ... The unconcern with which an hysteric regards a mass of foreign bodies, including dinner forks and pieces of sharp metal, in his intestinal tract is very striking."

In a few instances an element of concern in not wishing to cause too much bodily harm to himself is evidenced by previous removal of the prongs of a fork or the ladle end of a spoon. These individuals are usually hysteric delinquents. One patient swallowed some cotton-wool before taking 9 foreign bodies, presumably with the object of lessening the risk of impaction or perforation.

\section{Treatment}

Where the condition is quiescent, palliative measures are given for a reasonable length of time. These consist simply of a dietary such as porridge, bread, pease-brose, vegetables, and perhaps chopped-up string. Periodic $x$-ray examination is carried out, and, in the case of operative measures, as near as possible before operation. Careful examination of all stools and vomit should of course be made. Small articles may ultimately be assisted from the rectum by enema, by digital aid, or through the proctoscope. In general, 6 weeks may be taken as a rough guide to the period a foreign body which is producing no symptoms may be left in situ. Finally, in suitable cases-chiefly accidental-the patient's fears should be allayed by the reassuring attitude of the medical attendant.

The Table shows a series of 16 cases that were sent to hospital for surgical treatment between 1936 and 1939. Cases considered not urgent were observed for a variable period and checked up by $x$-ray examination. The minimum time a large foreign body remained in the stomach before extraction was 6 days. In urgent cases requiring operation reliance had to be placed on the history and clinical signs, with or without previous $x$-ray examination.

\section{Points of Interest}

From these sixteen cases it may be of interest to note that:

(a) Eight were found perforated, as follows: duodenum, 1 (Case 1); jejunum, 1 (Case 3); lower ileum, 1 (Case 12); caecum, 1 (Case 6); transverse colon, 2 (Cases 2, 8); pelvic colon, 1 (Case 5); right inguinal canal (? caecum or ileum), 1 (Case 7).

(b) All these perforations were in situations distal to the pylorus, 4 of them distal to the ileo-caecal valve.

(c) The case incidence of perforation in this series was $50 \%$, and all beyond the pylorus. This indicates that the patient is not necessarily out of danger when a foreign body has managed to pass the pylorus.

(d) With the exception of Cases 6, 7, and 8 the cases of perforation presented signs of acute abdomen with sudden and intense onset.

(e) Case incidence of impaction with intestinal obstruction was nil.

( $f$ ) Case incidence of impaction in the second part of the duodenum or at the ileo-caecal valve was nil.

(g) In no case did an ordinary intact fork or dessert-spoon, average length 7 in., or other article more than 1 in. in width, pass through the pylorus (Cases $4,11,13,14,15,16$ ). (h) The widest article that passed through the pylorus was 1 in. (Case 2)-a piece of tin.

(i) The longest articles that traversed the duodenum were $5 \frac{1}{4}$ in. and 5 in. (Cases 8, 12)-broken dessert-spoons.

(j) The widest article that passed the ileo-caecal valve was 1 in. (Case 2) and the longest $5 \frac{1}{4}$ in. (Case 8).

(k) In one case in which a similar operation-gastrotomyhad been performed 7. weeks previously no evidence of the former wound on the stomach wall was visible (Case 15).

(l) Case mortality: 15 recovered, 1 died $(6.25 \%)$.

Although the series of cases is a limited one and the type of foreign body rather different from and larger than that found in accidental cases, it is submitted that some findings at operation appear to run counter to certain of the views expressed in well-known textbooks on surgery and therefore may be considered unusual in this respect.

Choyce's System of Surgery (1932) states that: "The great majority of foreign bodies, having successfully passed the pylorus, safely traverse the remaining segments of the alimentary canal. The most common site of arrest is the lower part of the ileum, ileo-caecal valve, or caecum." Romanis and Mitchiner (Surgery, 1941) say that "foreign bodies are not commonly met with in the intestine as, if they pass through the pylorus, they will probably traverse the whole intestinal length and emerge at the anus. Elongated or heavy bodies will become impacted occasionally in the second part of the duodenum, and the only other point at which impaction is likely to occur is the neighbourhood of the ileo-caecal valve."

Maingot points out in his Post-graduate Surgery: "Very rarely does a foreign body, swallowed accidentally or intentionally, become lodged in the intestine. If perforation occurs the process is usually slow, resulting in either a localized abscess or an internal or external fistula." Rose and Carless's Manual of Surgery (16th edition, revised by Wakeley and Hunter, 1940) states: "Foreign bodies accidentally or intentionally swallowed occasionally pass through the stomach and become lodged in the intestinal canal. Lunatics and children are most frequently affected, and in the former the most astonishing collections are occasionally found. The symptoms caused by such conditions will be either those of intestinal obstruction or perforation. In the latter the process is usually gradual, rather than sudden, giving time for adhesions to form, thereby limiting the mischief. Suppuration follows, and possibly the foreign body may be extruded naturally or removed by the surgeon through the abscess cavity. Fragments of glass or metal may sometimes lodge in the pouches of the colon."

In the series under review the majority of the articles that had passed the pylorus and ileo-caecal valve were retained in the large bowel with signs of impaction or perforation. The sacculations, pouches, flexures, and sluggish peristalsis of the large intestine doubtless facilitate lodgment and, in some cases, perforation.

\section{Commentary}

Commenting briefly on certain cases, it may be mentioned that in Case 10 a small single tooth denture was searched for-on account of the haematemesis-but without success. This body may have eluded discovery by lodging in a duodenal pouch or diverticulum. The main point was its departure from the stomach and the subsequent freedom from symptoms. In Case 7 the supposition was a quiescent perforation by the needle through the caecum or lower ileum into the internal inguinal ring. This patient had undergone two abdominal sections previously and admitted to three separate occasions of foreign-body swallowing-a statement which was borne out by $x$-ray examination in each case. No. 12 was the only patient certified insane. He had no previous foreign-body history. In Case 9 operation was considered urgent, and was carried out the same night upon the history and failure of oesophagoscopy elsewhere. The transgastric approach was made. The location and extraction of the lower end of the foreign body (an impacted dessert-spoon) were difficult. Owing to the depth and curve, and to the failure of all ordinary 
forceps-curved or angular-to reach it, recourse was had to Cheatle's sterilizing forceps, which proved successful.

Recovery took place in all patients but one (Case 8), who died 24 hours after operation. He had a history of 3 former laparotomies for foreign bodies. The post-mortem findings showed small haemorrhages in the intestinal tract, atheroma, and myocardial degeneration.

\section{Conclusion}

It might be worth while recording a somewhat baftling case of trauma from a foreign body inserted into the lower orifice of the alimentary tract. There was a history of about 6 months' intermittent bleeding per anum whilst at another institution. There the patient was investigated on many occasions. Piles were suspected, and were injected. As bleeding continued he was removed to a hospital, where sigmoidoscopy and barium $x$-ray examination were carried out. Finally the patient consented to an abdominal exploration, which also gave a negative result. He was, however, much improved, and for a time there was no bleeding; later it recurred after leaving hospital. On admission to the surgical unit he appeared anaemic and wasted, with much loss of strength. His colour index was 0.9 and the red cells $3,500,000$ per c.mm. Bleeding per rectum was present, mixed with faeces; wash-outs contained blood and occasional clots. Examination by proctoscope showed a deeply injected and

Table showing Details of Cases

\begin{tabular}{|c|c|c|c|c|c|c|c|}
\hline \multirow{2}{*}{$\begin{array}{l}\text { Case } \\
\text { No. }\end{array}$} & \multirow{2}{*}{$\begin{array}{l}\text { Description of } \\
\text { Foreign Bodies }\end{array}$} & \multirow{2}{*}{ When taken } & \multirow{2}{*}{$\begin{array}{l}\text { Past F.B. } \\
\text { History }\end{array}$} & \multirow{2}{*}{$\begin{array}{l}\text { Condition } \\
\text { on Admișsion }\end{array}$} & \multicolumn{2}{|r|}{ Findings at Operation } & \multirow{2}{*}{ Result } \\
\hline & & & & & Peritonitis & Location & \\
\hline 1 & $\begin{array}{l}\text { Two 2 } \frac{1}{2} " \text { needles, bits of } \\
\text { glass, copper wire (the } \\
\text { two latter passed before } \\
\text { operation) }\end{array}$ & 8 weeks before & Nil & $\begin{array}{l}\text { Nausea. } \\
\text { epigastric } \\
\text { and right } \\
\text { pain } \\
\text { rigidity }\end{array}$ & $\begin{array}{c}\text { Present ; } \\
\text { localized }\end{array}$ & $\begin{array}{l}\text { (1) Needle in pyloric antrum of } \\
\text { stomach-impacted } \\
\text { (2) Needle in first part of duo- } \\
\text { denum-perforated }\end{array}$ & Recovered \\
\hline 2 & $\begin{array}{l}\text { Piece of tin }\left(3^{\prime \prime} \times 1^{\prime \prime}\right) \text {, pen- } \\
\text { holder }\left(41^{\prime \prime}\right) \text {, pocket-knife } \\
\left(3^{\prime \prime}\right) \text {, toothbrush handle } \\
\left(41^{\prime \prime}\right) \text {, small wooden spoon, } \\
4 \text { nails. (Maximum width } \\
\text { of F.B.s other than the } \\
\left.\text { first was } 4^{\prime \prime}\right)\end{array}$ & $\begin{array}{l}2 \text { and } 8 \text { days } \\
\text { before }\end{array}$ & $\begin{array}{l}\text { Laparotomy } \\
\text { for F.B. in } \\
\text { stomach } 2 \\
\text { years ago }\end{array}$ & $\begin{array}{l}\text { Acute abdomen ; } \\
\text { very ill }\end{array}$ & $\begin{array}{l}\text { Present ; } \\
\text { central }\end{array}$ & $\begin{array}{l}\text { (1) Piece of tin in transverse } \\
\text { colon-perforated } \\
\text { (2) Other articles-except nails } \\
\text {-found lying free in } \\
\text { pelvic colon } \\
\text { (3) Nails felt free in rectum and } \\
\text { left-passed } 4 \text { days later }\end{array}$ & , \\
\hline 3 & $\begin{array}{l}\text { Three large needles (tri- } \\
\left.\text { angular, pointed, } 3^{\prime \prime}\right) \text { one } \\
2^{\prime \prime} \text { needle. } 2 \text { bits of wire, } \\
1 \text { piece of tin, } 1 \text { piece of } \\
\text { wood, 1 slate-pencil. } \\
\text { (Maxinum width of F.B.s } \\
3^{\prime \prime} ; \text { length } 4^{\prime \prime} \text { ) }\end{array}$ & 14 days before & Nil & $\begin{array}{l}\text { Acute abdomen ; } \\
\text { very ill }\end{array}$ & $\begin{array}{l}\text { Present ; } \\
\text { gas and } \\
\text { free } \\
\text { fluid in } \\
\text { pelvis }\end{array}$ & $\begin{array}{l}\text { (1) One needle found free in } \\
\text { peritoneal cavity-perfor- } \\
\text { ated through jejunum } \\
\text { (2) Other needles, wire, tin, } \\
\text { and wood found lying } \\
\text { free in stomach } \\
\text { (3) Slate-pencil free in jejunum } \\
\text { (4) Doughy mass felt in ileum- } \\
\text { ? wool ; left alone }\end{array}$ & $"$ \\
\hline 4 & $\begin{array}{l}\text { Table fork (less prongs), } \\
\text { length } 5 \frac{1}{2}{ }^{\prime \prime}, \text { width } \frac{7}{8}^{\prime \prime}\end{array}$ & 6 days before & $\begin{array}{l}\text { Two former } \\
\text { abdominal } \\
\text { operations } \\
\text { for F.B.s }\end{array}$ & $\begin{array}{l}\text { Nausea. Slight } \\
\text { pain and tender- } \\
\text { ness over left } \\
\text { epigastrium }\end{array}$ & No & $\begin{array}{l}\text { Broken end of fork near greater } \\
\text { curvature of stomach-im- } \\
\text { pacted ; other end in pyloric } \\
\text { antrum-impacted }\end{array}$ & ", \\
\hline 5 & One $3^{\prime \prime}$ needle & $\begin{array}{l}7 \text { days before. } \\
\text { Stated by } \\
\text { accident }\end{array}$ & $\begin{array}{l}19 \text { days before } \\
\text { (Same patient } \\
\text { as Case } 3 \text { ) }\end{array}$ & Acute abdomen & $\begin{array}{l}\text { Present ; } \\
\text { localized } \\
\text { to lower } \\
\text { abdomen }\end{array}$ & $\begin{array}{l}\text { Needle found in pelvic colon } \\
\text { with point perforating through } \\
\text { wall. Ileus present. Many } \\
\text { adhesions from former peri- } \\
\text { tonitis }\end{array}$ & , \\
\hline 6 & One $3 "$ needle & $\begin{array}{c}3 \text { weeks before. } \\
\text { Accident }\end{array}$ & Nil & $\begin{array}{l}\text { Tender in right } \\
\text { iliac fossa over } \\
\text { McBurney's } \\
\text { point }\end{array}$ & No & $\begin{array}{l}\text { Needle found perforating wall } \\
\text { of caecum at a point } .12 \text { " below } \\
\text { appendix. Omentum wrapped } \\
\text { round protruding needle. Sur- } \\
\text { rounding area of caecum and } \\
\text { appendix acutely inflamed }\end{array}$ & , \\
\hline 7 & One $2 \frac{1}{2} "$ needle & Unknown & $\begin{array}{l}\text { Same patient } \\
\text { as Cases } 3 \\
\text { and } 5 \text { (five } \\
\text { mths. later) }\end{array}$ & $\begin{array}{l}\text { Pain and tender- } \\
\text { ness over right } \\
\text { inguinal region; } \\
\text { small lump, no } \\
\text { impulse }\end{array}$ & - & $\begin{array}{l}\text { Needle removed from right } \\
\text { inguinal canal near internal } \\
\text { ring. Much fibrous tissue } \\
\text { present. No evidence of } \\
\text { hernia or recent bowel per- } \\
\text { foration }\end{array}$ & , \\
\hline 8 & $\begin{array}{l}\text { One dessert-spoon (handle } \\
\text { and shaft only), length } \\
51^{\prime \prime} \text {, width }\end{array}$ & 10 days before & $\begin{array}{l}\text { Three former } \\
\text { abdominal } \\
\text { operations } \\
\text { for F.B.s }\end{array}$ & Acute abdomen & No & $\begin{array}{l}\text { Spoon found in transverse colon } \\
\text { impacted and on point of per- } \\
\text { forating. Many adhesions } \\
\text { present }\end{array}$ & $\begin{array}{l}\text { Died } 24 \\
\text { hours } \\
\text { later }\end{array}$ \\
\hline 9 & $\begin{array}{l}\text { One dessert-spoon, length } \\
7^{\prime \prime}, \text { width of spoon } 1_{2}^{\prime \prime} ; \\
\text { one } 2 !^{\prime \prime} \text { needle }\end{array}$ & 4 days before & $\begin{array}{l}\text { Two former } \\
\text { abdominal } \\
\text { operations } \\
\text { for F.B.s }\end{array}$ & $\begin{array}{l}\text { Dysphagia. Pre- } \\
\text { sternal pain. } \\
\text { Frequent retching. } \\
\text { Inanition debility. } \\
\text { Attempted remov- } \\
\text { al by means of } \\
\text { oesophagoscope } \\
\text { at another hos- } \\
\text { pital } 2 \text { days ago, } \\
\text { but failed }\end{array}$ & - & $\begin{array}{l}\text { (1) Spoon impacted in oesopha- } \\
\text { gus. Tip of handle located } \\
3 \frac{1}{2} \text { " above cardiac orifice } \\
\text { by transgastric section. } \\
\text { Impaction of ladle end of } \\
\text { spoon near level of tracheal } \\
\text { bifurcation. Difficult ex- } \\
\text { traction by use of Cheatle's } \\
\text { long sterilizer forceps } \\
\text { (2) Needle removed from trans- } \\
\text { verse colon }\end{array}$ & Recovered \\
\hline 10 & $\begin{array}{l}\text { One small denture-single } \\
\text { incisor with metal clip, } \\
\hat{t}^{\prime \prime} \times \underline{z}^{\prime \prime}\end{array}$ & $\begin{array}{l}8 \text { days before. } \\
\text { Accident }\end{array}$ & Nil & $\begin{array}{l}\text { Two attacks of } \\
\text { haematemesis. } \\
\text { Pain and vomit- } \\
\text { ing. } X \text {-rayed on } \\
\text { two occasions; } \\
\text { second on day } \\
\text { of operation }\end{array}$ & No & $\begin{array}{l}\text { Stomach carefully examined by } \\
\text { palpation externally, also } \\
\text { whole of small intestine, lesser } \\
\text { sac, and transverse colon- } \\
\text { five times. F.B. could not be } \\
\text { detected. Convalescence un- } \\
\text { eventful }\end{array}$ & 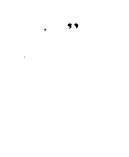 \\
\hline 11 & $\begin{array}{l}\text { One dessert-spoon (minus } \\
\text { handle), length } 6^{\prime \prime} \text {, width } \\
\text { of spoon end } 1 \frac{t^{\prime \prime}}{}\end{array}$ & 4 weeks before & " & $\begin{array}{cc}\text { Epigastric } & \text { pain. } \\
\text { Nausea. } & X \text {-ray } \\
\text { report: } & \text { "in } \\
\text { transverse colon },\end{array}$ & ", & $\begin{array}{l}\text { Spoon found in stomach with } \\
\text { broken end of shaft impacted } \\
\text { at greater curvature }\end{array}$ & , \\
\hline 12 & $\begin{array}{l}\text { Handle and shaft of spoon, } \\
\text { length 5", width of handle } \\
3^{\prime \prime} ; \text { one safety-pin (open) }\end{array}$ & $\begin{array}{l}\text { Unknown. } \\
\text { Insane }\end{array}$ & ", & $\begin{array}{l}\text { transverse colon } \\
\text { Acute abdomen }\end{array}$ & $\begin{array}{l}\text { Present; } \\
\text { localized }\end{array}$ & $\begin{array}{l}\text { Spoon handle and safety-pin } \\
\text { found in lower ileum, which } \\
\text { was perforated in two places. } \\
\text { Intestinal contents had es- } \\
\text { caped into pelvic cavity }\end{array}$ & ," \\
\hline 13 & One fork, length $6 \frac{7 "}{8}$, width & 10 days before & 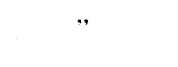 & $\begin{array}{l}\text { Nausea. Epigas- } \\
\text { tric pain. Right } \\
\text { rectus rigidity }\end{array}$ & No & $\begin{array}{l}\text { Fork found in stomach-im- } \\
\text { pacted between greater and } \\
\text { lesser curvatures }\end{array}$ & , \\
\hline 14 & One fork-size as Case 13 & 7 days before & $"$ & $\begin{array}{l}\text { Nausea. Retching. } \\
\text { Epigastric pain }\end{array}$ & , & $\begin{array}{l}\text { Fork found lying free in stomach } \\
\text { handle towards pyloric antrum }\end{array}$ & , \\
\hline 15 & One fork-size as Case 13 & Unknown & $\begin{array}{l}\text { Laparotomy } \\
\text { for F.B. } 7 \\
\text { weeks before } \\
\text { (Same patient } \\
\text { as Case 14) }\end{array}$ & $\begin{array}{l}\text { Symptoms as } \\
\text { above }\end{array}$ & ", & $\begin{array}{l}\text { Fork found free in stomach- } \\
\text { handle presenting. Scar of } \\
\text { former gastrotomy not visible }\end{array}$ & , \\
\hline 16 & $\begin{array}{l}\text { One fork (size as Case 13), } \\
3 \text { steel rings, } 11^{\prime \prime} \text { diameter }\end{array}$ & 6 days tefore & Nil & $\begin{array}{l}\text { Nausea. Occa- } \\
\text { sional vomiting. } \\
\text { Epigastric pain }\end{array}$ & , & $\begin{array}{l}\text { Fork found free in stomach, } \\
\text { also rings, although the latter } \\
\text { were somewhat elusive }\end{array}$ & , \\
\hline
\end{tabular}


velvety appearance of the anal mucosa and lower third of the rectum. Above this area the surface was normal. Some form of self-infliction was suspected, and close observation was kept for several weeks without result. All this time the patient was kept in bed on a milk diet. It might be mentioned that he was most co-operative in treatmerit, grateful for all that was being done, and often expressed a profound wish to get better. He was alert, intelligent, and an ardent book reader. At length the mystery was solved. While the patient was in the theatre for a final proctoscopy an intensive search, one of many, was being made of his bed and belongings. Concealed in the binding of a library book were found two pieces of twisted wire, 2 to 3 inches in length, with the ends set apart at one extremity-designed to create- trattma and haemorrhage. The wire had a faecal odour. Confirmatory examination by microscope and spectroscope revealed blood cells, B. coli, and a haemoglobin absorption band. From this moment the patient rapidly got well.

I should like to express my thanks to the Commissioners, H.M. Prison Commission, Home Office, for permission to publish this paper, though it does not necessarily represent their views.

\section{PERIODIC MEDICAL EXAMINATION}

BY

\section{FRANK ELLIS, M.B., M.Sc., F.F.R., D.M.R.}

Since periodic medical examination was suggested by Dobell (1861) it has made little or no headway. This may be due to medical apathy, since it is easier to work as individuals in medicine, but almost impossible to carry out such examinations without organization. On the other hand, it may be due to the fact that considered medical opinion disapproves of the principle, regards the procedure as scientifically unsound, ineffective, or impracticable, or regards the necessary administration and organization as too difficult under conditions hitherto existing in medicine and its relation to society. There is such attraction, however, in the idea that by periodic examinations minor tendencies to major maladies can be detected and thus corrected relatively easily before breakdown of the organism occurs that I think the evidence on the question should be reviewed, and the possibilities of the applicability and value of such examination assessed.

The great fault of the present method of bringing the doctor to the patient is that in most cases the doctor is not called at the beginning of ill-health, but when the compensation which is characteristic of the vital organism is failing the individual in his attempt to live up to his usual standard of efficiency. Periodic examinations, if they offered an opportunity for detection and correction before this failure of compensation occurred, would constitute an important branch of the preventive medicine which is rightly emphasized in the Medical Planning Commission's interim report (1942) as one of the most important functions of the medical practitioner.

\section{Studies from the Literature}

Sir James Mackenzie was able to make his contribution to modern cardiology as a result of carrying out regular examinations, and he emphasized the necessity for a systematic study of the beginnings of disease. Apart from the work of his disciples at St. Andrews, however, nothing on the subject has been reported in this country except from the Peckham Health Centre (1938). In America, following recommendation of the procedure by Dr. Gould in 1905, various sporadic individual attempts have been made to carry out such examinations, the most noteworthy being those of the Life Extension Institute, an account of which is given by Fisk (1923) and Fisk and Crawford (1927). Like the Peckham group, they report a high incidence of unsuspected defects in the apparently healthy. They assess the ratio of major to minor maladies as $1: 10$, and stress the fact that considerable relief follows the correction of minor complaints. Other published work is mostly American, and the relatively high incidence of defects in apparently healthy individuals is supported by Page (1938), Faught (1939), Ryan
(1927), Griswold (1940), Brandabur (1937, 1940), Harrison (1938), and Emerson and Irving (1938). From the Continent comes similar evidence (Kattentidt, 1933).

Assuming that such defects can be found, it is important to know if they can be corrected. The Peckham report says the course of many maladies has been arrested with success and with satisfaction to the sufferer. Improvement in various conditions on subsequent examination is reported by the workers mentioned above, correction of from 50 to $70 \%$ of defects of all kinds being recorded. Noteworthy among these are reports of improvement and disappearance of hypertension following hygienic measures only (adjusted habits of life, etc.) by Brandabur and by Emerson and Irving. The former reports a recovery to normal in 114 out of 382 railway workers, and the latter report an average reduction in blood pressure of $18 \mathrm{~mm}$. of mercury in 78 out of 120 sufferers found in 1,020 examinees. When it is remembered that the actuarial assessment of actual to expected deaths of men aged 40 to 49 is improved from 138 to $97 \%$ as a result of $10 \mathrm{~mm}$. difference in blood pressure, the importance of these results can be appreciated (Actuarial Society of America, 1939).

\section{Improved Expectation of Life}

This appreciation based on ordinary life insurance examinations nullifies possible criticisms of the significance of these blood-pressure estimates. Caution because of possible inaccuracies in ordinary estimates is necessary, as emphasized by Bethea and Hardy (1932). The thoroughness of the periodic examinations cetermines the number and the nature of the defects recorded, but Mishler (1939) reports on the employees of a "Truck Line" system, $40 \%$ of whom were found to have defects on examination by general practitioners distributed over a wide area, while the Life Extension Institute (Fisk, 1923) found some defect in all of 10,800 males of an average age of 34 from typical industrial groups. That improvement in expectation of life results from such examinations is shown by a report of the Metropolitan Life Insurance Company of New York (Fisk, 1923). It is stated that instead of a mortality rate for seriously impaired life of $2 \frac{1}{2}$ times the tabular rate, it was only $82 \%$ of the tabular rate, and 38,000 lives were saved for the company in 1920 .

In spite of the value of the procedure as indicated by these published findings, and although the American Medical Association publicly endorsed the principle of periodic medical examinations in 1922, the apparent popularization of such examinations in the United States is only relative. This is shown by Collins (1934), senior statistician to the United States Public Health Service, who, in a survey of a cross-section of 8,758 families, found that only $3 \%$ of the population at the age of 60 underwent periodic examinations, and that this was the maximum proportion after the age of 20 . Thus it would seem that unorganized voluntary examinations only touch on the problem, and that a national effort is needed to make examinations an important part of preventive medicine. Organized examinations have been reported from France, Germany, Turkey (Asim Arar, 1938), and Russia (Fredlyand, 1938), while in Canada, Harrison (1938) states, " recent Canadian Provincial Health Insurance Acts make provision for periodic health examination."

It is my contention that all this evidence calls for the serious consideration of periodic medical examination on a national scale as part of our post-war medical organization. In addition to the immediate benefit to the individual which can reasonably be expected, it is anticipated that with adequate statistical analysis of thea findings carried out at central bureaux the significance of hitherto unappreciated facts in clinical history and examination will be assessed, with the result that early diagnosis of disease will be facilitated, and the emphasis in medicine will be on the physiological rather than, as at present, on the pathological. Such a scheme is not beyond the bounds of practicability. The cost should be a national concern, and it must not be forgotten that the saving of life and health would, taking the long view, probably more than pay for it. Fisk shows that for $105,000,000$ people in America the gain, after deducting the cost of examinations and treatment, represented about $\$ 1,500,000,000$; a proportional figure for the United Kingdom would be $£ 100,000,000$ a year. 